(c) All rights are reserved by Kudekar DY et al.

\title{
Blood of Accused - Vital Scientific Evidence in Crime of Rape
}

\section{Keywords}

DNA; Polymerase chain reaction; Denaturation; STR; Genotyping

\begin{abstract}
Rape is a heinous crime and lot of rape crimes are registered in Maharashtra day to day. In case of a minor victim, medica examination plays important role to prove the rape. For the forensic analysis, forensic science laboratory receives the samples collected by medical officers during the medical examination of victim and accused and the other samples of them like clothes, crime scene articles seized by investigation agency. In the crime of rape, semen of accused on clothes of victim or in genital parts of victim is always the crucial scientific evidence which can prove the act of crime and can led severe punishment by law. However, every time it is not possible to obtain semen on articles as sometimes ejaculation of semen may not be achieved by the culprit. In such situations, blood also plays important role to connect the accused with the crime. We analyzed two such cases where, DNA profiles obtained from blood detected on victim's clothes matched with DNA profiles of accused. However as the cases were belonged to rape, accused were adult and both victims were minor, the transfer of blood of accused on their clothes was astonishing. After studying medical examination report of both the accused, it was found that they had penile injuries while attempting the crime. So, in absence of semen; the DNA profile obtained from blood on victim's clothes found the crucial evidence in both the cases which proved the involvement of accused in the crime.
\end{abstract}

\section{Introduction}

Recently there has been tremendous rise in sexual offences against women and more dangerous fact is that the number of minor victims in such crimes is more. Census data from 2011 shows that in India 472 million children below age of eighteen and out of them 225 million are girls [1]. Many times due to pressure and lack of knowledge, these children fear to talk about atrocious crime. India has taken lot of precautions since the Nirbhaya case happened and made legal provision of new act "Protection of Children from Sexual Offences Act 2012 (POCSO Act 2012)" and continuously monitoring these cases [2]. To increase conviction rate, scientific evidence has lot of importance and DNA evidence is the one of best evidence. If this evidence is found, court can send culprit to rigorous imprisonment considering DNA report.

While performing forensic analysis of exhibits seized in sexual offences, though semen is absent in medical samples like vaginal swab, pubic hair or on her clothes, if blood of accused is found on her exhibits, it can play a vital evidence to prove the crime. This evidence of blood is very much important in specifically minor victims. Because in such crimes, it is observed that most of the times, accused fails to intercourse and ejaculate semen because of smaller opening of vagina of minor girl and he himself gets penile injuries while forceful attempt. Blood detected in such cases is important to prove the crime [3]. We solved such two cases in our forensic science laboratory.

\section{Sournal of \\ Forensic \\ Investigation}

\author{
Kudekar DY ${ }^{1 *}$, Mahajan VB ${ }^{1^{*}}$, More BP ${ }^{1}$, Kawade JR \\ and Kulkarni KV ${ }^{2}$
}

${ }^{1}$ Regional Forensic Science Laboratory, Home Department, India ${ }^{2}$ Directorates of Forensic Science Laboratories, Home Department, India

\section{*Address for Correspondence}

Kudekar DY, Regional Forensic Science Laboratory, Government of Maharashtra, Home Department, Dindori Road, Nashik 440002, Maharashtra, India; Phone/Fax (O): 0253-2620573, Mob: 8898267006; E-mail: deepak.kudekar99@maharashtra.gov.in

Mahajan VB, Regional Forensic Science Laboratory, Home Department, India Email: vaishalimahajan.nagpur@gmail.com

Submission: 16-July-2020

Accepted: 12-August-2020

Published: 19-August-2020

Copyright: (c) 2020 Kudekar DY, et al. This is an open access article distributed under the Creative Commons Attribution License, which permits unrestricted use, distribution, and reproduction in any medium, provided the original work is properly cited.

In first case, registered in Nashik District, victim was 15 years old. One day she went to buy grocery to nearby shop. A known boy had taken advantage of her innocence and lured her. He took her in secluded place and raped her forcefully without her consent.

In the second case, registered in Jalgaon District, victim was only 9 years old. She was a special child with mental illness while culprit was 65 years old and he was her neighbor. The child was plying near her home; accused called her in his home and tried to rape her on iron bed.

In both the cases, investigation agencies sent seized cloths along with medical samples of victims and accused to Regional forensic science laboratory Nashik for forensic examination.

\section{Materials and Methods}

Prepfiler Express Kit (applied biosystem)

AmpFI STR Identifler kit (applied biosystem)

Forensic Buffer $\mathrm{p}^{\mathrm{H}} 8$

Proteinase K

Phenol: Chloroform: Isoamyl Alcohol (100:100:4)

Isopropanol

1) Automate Express Forensic DNA System

Kit Used: Prep filer Express

2) PCR Thermal Cycler Machine, Capacity: 96 well x 0.2 ml PCR Tubes

Capable of testing Temperatures: Denaturation, annealing and extension steps 


\begin{tabular}{|c|c|c|c|c|c|}
\hline \multirow{4}{*}{ STR LOCUS } & \multicolumn{5}{|c|}{ GENOTYPE } \\
\hline & Blood Stain & Blood Stain & Blood Stain & Semen Stain & Blood \\
\hline & Kurta & Jeans Pant & Underwear & Underwear & Accused \\
\hline & (Victim) & (Victim) & (Accused) & (Accused) & \\
\hline D8S1179 & 10,16 & 10,16 & 10,16 & 10,16 & 10,16 \\
\hline D21S11 & 28,29 & 28,29 & 28,29 & 28,29 & 28,29 \\
\hline D7S820 & 8,10 & 8,10 & 8,10 & 8,10 & 8,10 \\
\hline CSF1PO & 10,12 & 10,12 & 10,12 & 10,12 & 10,12 \\
\hline D3S1358 & 15,17 & 15,17 & 15,17 & 15,17 & 15,17 \\
\hline THO1 & 9,9 & 9,9 & 9,9 & 9,9 & 9,9 \\
\hline D13S317 & 8,11 & 8,11 & 8,11 & 8,11 & 8,11 \\
\hline D16S539 & 11,13 & 11,13 & 11,13 & 11,13 & 11,13 \\
\hline D2S1338 & 19,23 & 19,23 & 19,23 & 19,23 & 19,23 \\
\hline D19S433 & 12,16 & 12,16 & 12,16 & 12,16 & 12,16 \\
\hline vWA & 16,17 & 16,17 & 16,17 & 16,17 & 16,17 \\
\hline TPOX & 8,11 & 8,11 & 8,11 & 8,11 & 8,11 \\
\hline D18S51 & 12,14 & 12,14 & 12,14 & 12,14 & 12,14 \\
\hline AMELOGENIN & $X, Y$ & $X, Y$ & $X, Y$ & $X, Y$ & $X, Y$ \\
\hline D5S818 & 10,11 & 10,11 & 10,11 & 10,11 & 10,11 \\
\hline FGA & 24,25 & 24,25 & 24,25 & 24,25 & 24,25 \\
\hline
\end{tabular}

Case no.2, Table 2:

\begin{tabular}{|c|c|c|c|c|c|c|c|}
\hline \multirow{4}{*}{ STR LOCUS } & \multicolumn{7}{|c|}{ GENOTYPE } \\
\hline & Blood Stain & Blood Stain & Blood Stain & Blood Stain & Semen Stain & Blood & Blood \\
\hline & Frock & Knicker & Bed sheet & Mattress Cover & Mattress Cover & (Victim) & (Accused) \\
\hline & (Victim) & (Victim) & Crime Scene) & (Crime Scene) & (Crime Scene) & & \\
\hline D8S1179 & 12,14 & 12,14 & 12,14 & 12,14 & 12,14 & 15,16 & 12,14 \\
\hline D21S11 & $31.2,31.2$ & $31.2,31.2$ & $31.2,31.2$ & $31.2,31.2$ & $31.2,31.2$ & $32.2,32.2$ & $31.2,31.2$ \\
\hline D7S820 & 8,11 & 8,11 & 8,11 & 8,11 & 8,11 & 10,11 & 8,11 \\
\hline CSF1PO & 11,11 & 11,11 & 11,11 & 11,11 & 11,11 & 10,11 & 11,11 \\
\hline D3S1358 & 16,17 & 16,17 & 16,17 & 16,17 & 16,17 & 15,15 & 16,17 \\
\hline THO1 & 9,9 & 9,9 & 9,9 & 9,9 & 9,9 & 6,9 & 9,9 \\
\hline D13S317 & 9,11 & 9,11 & 9,11 & 9,11 & 9,11 & 8,8 & 9,11 \\
\hline D16S539 & 8,11 & 8,11 & 8,11 & 8,11 & 8,11 & 9,11 & 8,11 \\
\hline D2S1338 & 23,24 & 23,24 & 23,24 & 23,24 & 23,24 & 17,24 & 23,24 \\
\hline D19S433 & 14,16 & 14,16 & 14,16 & 14,16 & 14,16 & $13,15.2$ & 14,16 \\
\hline vWA & 16,16 & 16,16 & 16,16 & 16,16 & 16,16 & 17,18 & 16,16 \\
\hline TPOX & 8,11 & 8,11 & 8,11 & 8,11 & 8,11 & 8,11 & 8,11 \\
\hline D18S51 & 10,13 & 10,13 & 10,13 & 10,13 & 10,13 & 16,16 & 10,13 \\
\hline AMELOGENIN & $X, Y$ & $X, Y$ & $X, Y$ & $X, Y$ & $X, Y$ & $\mathrm{x}, \mathrm{X}$ & $X, Y$ \\
\hline D5S818 & 11,11 & 11,11 & 11,11 & 11,11 & 11,11 & 11,11 & 11,11 \\
\hline FGA & 20,20 & 20,20 & 20,20 & 20,20 & 20,20 & 20,20 & 20,20 \\
\hline
\end{tabular}

Heating/ Cooling: Peltier based Temperature accuracy- $\pm 0.2^{\circ} \mathrm{C}$

Temperature accuracy- $\pm 0.2^{\circ} \mathrm{C}$

3) Genetic analyzer, Fragment size: 600bp

Number of markers: 16 for I- filer; Polymer: POP4

Oven Temp: 600 C, Column Size: $36 \mathrm{~cm}$

Software: Gene Mapper

\section{Steps used in analysis}

Detection of Blood and semen: In the first case, our laboratory had received clothes of victim, accused and medical samples like vaginal swabs, pubic hair, nail clippings and reference blood sample of victim and pubic hair, penile swab, nail clippings, reference blood sample of accused. During detection of all the exhibits, blood was detected only on kurta, jeans pant of victim and underwear of accused. Semen was detected on underwear of accused. No semen was detected on victim's clothes as well as medical samples.

In the second case, our laboratory had received clothes of victim, accused and crime scene bed sheet, mattress cover. Similarly, medical samples of victim and accused collected by medical officer during medical checkup. While analysis, the blood was detected on frock, knicker of victim and also on bed sheet and cover of mattress. Semen was detected on cover of mattress. No semen was detected on clothes of victim and accused. Neither blood nor semen was detected on medical samples of both.

Routine Kastle -Meyer solution was used for detection of blood [4,5].

Semen was detected on cover of mattress using acid phosphatase test [6]. 
Extraction of DNA:- In the first case, the DNA was extraction from blood detected on kurta, jeans pant of victim, underwear of accused and semen detected on underwear of accused. In the second case, DNA was extracted from blood detected on frock, knicker of victim and bed sheet from crime scene and semen detected on cover of mattress. The DNA extraction was done using Automate Express machine using PrepFiler ${ }^{\mathrm{TM}}$ Express DNA extraction kit [7]. The PrepFiler ${ }^{\mathrm{TM}}$ Forensic DNA extraction Kit (Applied Biosystems, Foster City, CA) is efficient for isolation of DNA from a variety of biological samples that contain small quantities of biological material so that if traces of undetected semen are present in blood on cloths or medical samples, male DNA can be extracted from blood mixed semen using this kit [7-9]. The protocol used for extraction was as follows.

1. Blood stains on all the positive articles were cut into small $1 \mathrm{x} 1$ $\mathrm{mm}$ pieces and were placed in $2 \mathrm{ml}$ micro centrifuge tube.

2. $500 \mu \mathrm{l}$ Lysis buffer from PrepFiler Express F DNA extraction kit (19) was added to all the sample tubes.

3. The sample tubes were kept on thermo shaker at $750 \mathrm{rpm}$ at 70 ${ }^{\circ} \mathrm{C}$ for $40 \mathrm{~min}$.

4. The tubes were then centrifuged at $10,000 \mathrm{rpm}$ for $2 \mathrm{~min}$.

5. Cartridges from PrepFiler Express F DNA extraction kit were loaded to the cartridge rack in Automate Express DNA extraction system (20), Sample tubes, elution tubes and tips were loaded as per machine guidelines and the machine program was run as per the recommended machine protocol.

6. After completion of program, elution tubes containing extracted DNA in highly pure form were stored at $4^{\circ} \mathrm{C}$ till the next PCR amplification process.

Many different methods are available for extraction of DNA.

Routine organic extraction Phenol/Chloroform extraction method is quite sensitive method for the extraction of DNA from wide variety of forensic samples [10]. This organic extraction method was employed for extraction of DNA from reference blood samples of accused and victim in both the cases. In organic extraction method, samples were lysed using Forensic Buffer $\left(\mathrm{p}^{\mathrm{H}} 8\right)$, Proteinase $\mathrm{K}$, and Sodium Dodecyl Sulphate. Further samples were incubated for $2 \mathrm{hrs}$ at $56^{\circ} \mathrm{C}$ and Phenol: Chloroform: Isoamyl alcohol previously prepared solution was added. The aqueous layer containing DNA separated and treated with $2 \mathrm{M}$ Sodium Acetate and the DNA was precipitated using chilled Isopropanol. Finally extracted DNA dissolved in TE buffer $\left(\mathrm{p}^{\mathrm{H}} 7\right)$.

\section{Quantification of DNA}

Extracted DNA was quantified using Quantifiler human DNA kit on 7500 Real Time PCR System (Applied Biosystems) according to the protocol $[11,12]$. Proper diluted DNA sample was used for further PCR reaction.

\section{Polymerase chain reaction}

Quantified DNA of all the samples from both the cases was processed for PCR using AmpFISTR'Identifiler PCR amplification kit on Veriti Thermal Cycler of Applied Biosystems (Table 1 and 2) $[13,14]$. AmpFISTRTM IdentifilerTM primers amplify the STR loci
CSF1PO, D2S1338, D3S1358, D5S818, D7S820, D8S1179, D13S317, D16S539, D18S51, D19S433, D21S11, FGA, TH01, TPOX, vWA and gender marker Amelogenin.

Master mix used for Polymerase Chain Reaction was-

AmpFISTR PCR reaction mix: $10.5 \mu \mathrm{l}$

AmpFISTR Primer Set: $5.5 \mu \mathrm{l}$

Polymerase: $0.55 \mu \mathrm{l}$

Volume of Master mix used: $15 \mu \mathrm{l}$

Volume of DNA sample: $10 \mu \mathrm{l}$

After PCR amplification denaturation was carried out using $\mathrm{HiDi}$ Formamide and Liz 600 size Standard.

STR Genotyping:- After completion of PCR amplification of DNA, amplified DNA products were analyzed on 3500 Genetic Analyzer and processed using Gene Mapper ID-X Software V 1.5 according to manufacturer recommended procedure. Simultaneous amplification of 16 STR Loci was achieved [15-17]. DNA profiles obtained from above samples in both cases were interpreted and compared with each other.

\section{Results and Discussion}

In case no. 1 DNA profiles obtained from blood detected on kurta, jeans pant of victim, underwear of accused and semen detected on underwear of accused were found to be identical and from one and the same source of male origin and matched with DNA profile obtained from reference blood of accused ( Case no.1, Table no.1).

In case no. 2 The DNA profiles obtained from blood detected on frock and knicker of victim, bed sheet and cover of mattress from crime scene and semen detected on cover of mattress from crime scene found to be identical and from one and same source of male origin and matched with DNA profile of reference blood of accused (Case no.2, Table no.2).

\section{Conclusion}

As in both scenarios the victims of crime were minor girls. So, during the act of sexual offence bleeding from genitals of victim is natural. While analysis, the forensic expert probably expects either blood of victim or semen of accused on garments as well as on crime scene. But every time, it doesn't happen. Many times, accused tries for intercourse but being minor the vaginal opening is small and victim cries due to pain so, accused himself gets penile injuries in trying forceful intercourse, his blood may found on crime scene and garments of victim and accused. In both the cases analyzed in our laboratory, we got male DNA profiles from blood detected on clothes. When we inquired injury report of accused, it showed penile injuries while attempting the rape. In absence of semen on clothes or medical samples of victim; the DNA profile obtained from blood of accused itself proved that the profiles belong to accused, in addition to this, medical injury reports also support that both culprits got penile injuries. It is definitely a sufficient evidence to prove the guilt of accused in the court.

\section{References}


1. Census of India Website: Office of the Registrar General \& Census; www. censusindia.gov.in

2. The Gazette of India: Protection of Children from Sexual Offences Act, 2012 [No.32 OF 2012]19th June 2012

3. Mahajan VB, Kharade AP, Kudekar DY, More BP, Kulkarni KV (2019) Jot of Blood Sends Constable behind the Bars - Justice by DNA Profiling. Ann Clin Lab Res 7: 2: 305

4. Richard Li, Forensic Biology: Identification and DNA analysis of Bilogical Evidence (2008)

5. Kastle JH, Shedd OM (1901) Phenolphthalein as a reagent for oxidizing ferments. American Chemical Journal 26:526-539

6. Moul, Judd W., et al. "The Contemporary Value of Pretreatment Prostatic Acid Phosphatase to Predict Pathological Stage and Recurrence in Radical Prostatectomy Cases."Journal of Urology (March 1998): 935-940.

7. Liu JY, Zhong C, Lagace R, et al. (2012) Automate Express TM Forensic DNA extraction system for the Extraction of Genomic DNA from Biological Samples, J Forensic Sci 57: 1022-1030.

8. Brevnov MG, Pawar HS, Mundt J, Calandro LM, Furtado MR, et al. (2009) Developmental validation of the PrepFiler Forensic DNA Extraction Kit for extraction of genomic DNA from biological samples. J Forensic Sci 2009; 54:599-607.
9. Brevnov MG, Mundt J, Benfield J, Treat-Clemons L, Kalusche G, et al. (2009) Automated extraction of DNA from forensic samples types using the PrepFiler Automated Forensic DNA Extracrtion Kit. JALA 14: 294-302.

10. Kochl S, Niederstatter $\mathrm{H}$, Parson W (2005) DNA extraction and quantitation of forensic samples using the phenol-chloroform method and real-time PCR, Methods MolBiol 297: 13-30.

11. (2005) Applied Biosystems Quantifiler user's manual. Foster City, CA.

12. Barbisin M, Fang R, O'Shea CE, Calandro LM, Furtado MR, et al. (2009) Developmental validation of the Quantifiler Duo DNA Quantification kit for simultaneous quantification of total human and human male DNA and detection of PCR inhibitors in biological samples. J Forensic Sci 54: 305-319.

13. Applied Biosystems. AmpFISTR®Identifiler ${ }^{\circledR}$ PCR amplification kit user's manual, part \# 4323291 Rev. B. Foster City, CA: Applied Biosystems 2001.

14. Mullis K, Faloona F, Scharf S, Saiki R, Horn G, et al. (1986) Specific enzymatic amplification of DNA in vitro the polymerase chain reaction. Cold spring HarbSymp Quant Bio 51 pt 1: 263-273.

15. Applied Biosystems 3500/3500XL Genetic Analyzer User Guide Applied Biosystems, Faster City CA.

16. Budowle B, Allen RC (1998) Analysis of amplified fragment length polymorphism (VNTR/STR Loci) for human identity testing. Methods molBiol 98: 155-171.

17. Gill P, Kimpton CP, Urquhart A, Oldrod N, Millican ES, et al. (1995) Automated short tandem repeat (STR) Analysis in forensic casework-a strategy for the future. Electrophoresis 16: 1543-1552. 